\title{
Perilaku Pencarian Pengobatan dan Perawatan Mandiri pada Penderita Filariasis di Kabupaten Wonosobo
}

\author{
Ruth Puspita Dheo $^{*}$, Siti Masfiah ${ }^{*}$, , Arrum Firda Ayu Maghfiroh ${ }^{*}$ \\ *) Fakultas Ilmu-ilmu Kesehatan Universitas Jenderal Soedirman \\ Korespondensi: ruthdheo@gmail.com
}

\begin{abstract}
Background: Promptly treatment is essential for filariasis patients to reduce permanent disability. Preliminary study of several filariasis patients with swollen leg in Wonosobo regency indicated as delay access to promt treatment which increase the risks of transmision as well as worsen patient's condition. The purpose of this study was to explore health-seeking behaviour and self-care of patient in Wonosobo regency.

Method: This study employs qualitative research using phenomenology approach. Five informants were selected by using criteria as patients with clinically symptomatic swelling leg and willing to participate to this study. The supporting informants were selected to family members and health workers who handle filariasis treatment. All data were analyzed by using content analysis.
\end{abstract}

Results: Most filariasis patients were categorized as low income and having limited knowledge of the disease. They believed that the disease caused by curse so that medical treatment will not cure it and they have desperate with the illness. Psychosocial burden caused them feel anxiety even afraid to be outcasted. Their current condition mostly swollen legs with or without complications and the disease interferes their activity as very painful disease. Although the treatment will reduce pain, but it was only temporary, so that the patients felt that the treatment will be useless. The health seeking behaviour indicated that all patients experienced delay in accessing medical treatment, they tried to find other alternative treatment such as traditional treatment. Most patients have not yet performed good self-care as recommended by health workers. In addition, information and socialization about filariasis to patients, families and communities are limited because it has not been as priority program of health center. Health education program should be conducted to improve positive behavior of community regarding the prevention, early detection, prompt treatment and self-care of the disease.

Keywords: filariasis, health-seeking behaviour, self-care

\section{PENDAHULUAN}

Filariasis merupakan penyakit menular disebabkan cacing filaria yang menyerang saluran dan kelenjar getah bening manusia, sehingga berpotensi merusak sistem limfa serta menimbulkan pembengkakan pada tangan, kaki, payudara, dan kantung buah zakar. $^{(1)}$ Filariasis di Indonesia disebabkan oleh infeksi cacing filaria Wuchereria bancrofti,
Brugia malayi, dan Brugia timori yang ditularkan oleh beberapa spesies nyamuk seperti Mansonia uniformis dan Culex quinquefasciatus yang sering ditemukan sebagai vektor filariasis di Jawa Tengah. ${ }^{(2)}$ Meski tidak mengakibatkan kematian secara langsung, penyakit ini menjadi penyebab utama kecacatan, pengucilan, hambatan psikosisial, dan penurunan 
produktivitas kerja individu sehingga menimbulkan kerugian ekonomi. ${ }^{(3)}$

Persebaran kasus filariasis berdasarkan data WHO menunjukkan pada tahun 2014, filariasis menyerang 1.103 juta penduduk, di mana 632 juta kasusnya di Asia Tenggara. ${ }^{(4)}$ Pada tahun 2015, filariasis di Indonesia berjumlah 13.032 kasus, di mana 504 kasus Filariasis tersebut berada di Jawa Tengah. ${ }^{(5)}$ Kabupaten Wonosobo merupakan salah satu wilayah endemis filariasis di Provinsi Jawa Tengah, dengan microfillaria rate lebih dari satu persen. Dinas Kesehatan Kabupaten Wonosobo mencatat 16 kasus filariasis sejak 2005 hingga $2017 .^{(6)}$

Penyakit Filariasis jika tidak ditangani secara tepat dapat menimbulkan dampak negatif, diantaranya kecacatan seumur hidup atau irreversible sehingga menjadi beban psikososial yang berat diterima oleh penderita. ${ }^{(2)}$ Penelitian terdahulu tentang pengalaman hidup orang yang terinfeksi filariasis di Tasikmalaya menunjukkan tanggapan masyarakat yang kurang baik terhadap penderita filariasis, yaitu berupa tanggapan menjijikkan, takut tertular, hingga pengucilan terhadap penderita. ${ }^{(7)}$ Akibatnya, penderita tersebut merasa malu dan menarik diri dari interaksi sosial. Filariasis tidak menimbulkan dampak lebih besar apabila ditangani dengan baik, diantaranya dengan pencarian pengobatan dan perawatan ke layanan kesehatan sesegera mungkin. ${ }^{(1)}$ Akan tetapi, perilaku penderita filariasis di Kabupaten Wonosobo dalam mencari pengobatan filariasis menunjukkan adanya permasalahan, diantaranya para penderita tidak datang ke layanan kesehatan untuk berobat segera. Wawancara dengan petugas puskesmas menunjukkan beberapa kasus filariasis dengan pembengkakan kaki, baru diketahui setelah adanya laporan dari kader saat pendataan sasaran Pemberian Obat Pencegahan Massal (POPM) filariasis pada tahun 2016.

Selain memperbesar risiko penularan filariasis, pengobatan dan perawatan mandiri yang tidak dilakukan segera juga berpotensi memperburuk kondisi penderita. Berdasarkan latar belakang tersebut, peneliti ingin mengetahui lebih mendalam tentang gambaran perilaku pencarian pengobatan dan perawatan mandiri pada penderita filariasis di Wonosobo serta alasan-alasannya.

\section{METODE}

Penelitian ini merupakan penelitian kualitatif dengan pendekatan fenomenologi. Penelitian dilaksanakan di lima kecamatan yang terdapat kasus filariasis tertinggi di Kabupaten Wonosobo. Informan utama dipilih secara purposive sampling, yaitu penderita filariasis yang telah mengalami pembengkakan pada kaki, di mana pada masing-masing kecamatan diperoleh satu 
informan yang sesuai dengan kriteria tersebut sehingga jumlah informan dalam penelitian ini adalah lima orang. Sedangkan triangulasi dilakukan kepada informan pendukung yaitu keluarga terdekat seperti istri, saudara, ibu atau mertua, serta petugas kesehatan puskesmas yang menangani program filariasis. Data dikumpulkan dengan wawancara mendalam kepada semua informan dan dilaksanakan di tempat tinggal informan utama, serta dianalisis dengan content analysis.

\section{HASIL DAN PEMBAHASAN}

Informan utama penelitian ini seluruhnya sudah mengalami pembengkakan kaki dengan rentang usia antara 22-50 tahun, sebagian besar berpendidikan Sekolah Dasar (SD), dengan sosial ekonomi menengah ke bawah. Karakteristik informan dapat dilihat di tabel 1.
Analisis hasil penelitian mengenai perilaku pencarian pengobatan pada penderita Filariasis di Kabupaten Wonosobo menunjukkan temuan seluruh informan terlambat dalam mengakses pengobatan medis, karena rata-rata penderita sudah mengalami pembengkakan kaki dengan berbagai komplikasi. Keterlambatan mengakses pengobatan dimungkinkan karena pada umumnya penyakit filariasis kronis, baru diketahui setelah ada gejala pembengkakan bagian tubuh tertentu. Hal ini sejalan dengan penelitian lain tentang gambaran penderita filariasis di Kabupaten Meranti Provinsi Riau, yang menyatakan bahwa penderita filariasis biasanya baru mengetahui dirinya terkena filariasis setelah kaki maupun tangannya mengalami pembengkakan, dan biasanya ditemukan satu tahun keatas setelah terinfeksi cacing filaria. ${ }^{(8)}$

Tabel 1. Karakteristik informan penelitian

\begin{tabular}{|c|c|c|c|c|c|}
\hline Informan & Usia & $\begin{array}{c}\text { Jenis } \\
\text { kelamin }\end{array}$ & Pendidikan & Pekerjaan & Kondisi filariasis \\
\hline NSQ & 42 & Laki-laki & SD & Petani & $\begin{array}{l}\text { Kaki kiri bengkak besar, } \\
\text { luka kering, kulit tebal }\end{array}$ \\
\hline FTN & 22 & Perempuan & SMP & Pengangguran & $\begin{array}{l}\text { Kedua telapak dan } \\
\text { pergelangan kaki bengkak, } \\
\text { luka basah dan nanah di } \\
\text { sela jari kaki }\end{array}$ \\
\hline WLN & 50 & Perempuan & SD & $\begin{array}{l}\text { Pedagang dan } \\
\text { petani }\end{array}$ & $\begin{array}{l}\text { Kaki kiri bengkak besar, } \\
\text { tidak ada luka }\end{array}$ \\
\hline KWL & 50 & Perempuan & SD & Pijat keliling & $\begin{array}{l}\text { Kaki kanan pengkak, kulit } \\
\text { kering }\end{array}$ \\
\hline ZML & 30 & Laki-laki & SMP & Pengangguran & $\begin{array}{l}\text { Kaki kiri bengkak besar, } \\
\text { luka kering, kulit tebal, } \\
\text { kedua mata buta, } \\
\text { komplikasi ginjal }\end{array}$ \\
\hline
\end{tabular}


Predisposisi Pencarian Pengobatan dan Perawatan Mandiri

Pengetahuan tentang filariasis

Pengetahuan informan utama mengenai filariasis yang meliputi pengertian, penyebab, hingga gejala filariasis menunjukkan sebagian besar hanya mengetahui bahwa filariasis adalah penyakit kaki gajah, namun tidak mengetahui penyebab dari penyakit tersebut. Sedangkan dua informan lainnya beranggapan bahwa pembengkakan pada kakinya karena bawaan sejak kecil atau karena faktor keturunan. Kurangnya sosialisasi dari tenaga kesehatan tentang filariasis menyebabkan masyarakat tidak paham tentang penyakit tersebut. Penyakit filariasis belum menjadi prioritas program puskesmas, sehingga informasi yang diberikan kepada masyarakat juga sangat terbatas. ${ }^{(9)}$

"Ya kaki gajah.... Ya itu, ada apanya gitu, saya ndak tahu kan. Mungkin karena sudah bawaan dari kecil" (KWL, 50 tahun)

Karakteristik predisposisi pengetahuan terhadap filariasis menunjukkan sebagian besar informan dapat menjawab bahwa filariasis adalah penyakit kaki gajah, namun tidak dapat menjelaskan lebih lanjut seperti penyebab dari penyakit tersebut. Bahkan terdapat informan yang tidak mengetahui penyakit filariasis dan menganggap pembengkakan kakinya adalah bawaan sejak kecil. Sejalan dengan penelitian lain tentang tinjauan psikologi kesehatan pada penderita filariasis kronis di Kabupaten Bandung, yang menyatakan hanya $23 \%$ responden yang memiliki pengetahuan filariasis pada tahap hanya memahami sebutan penyakit filariasis, sedangkan sisanya yaitu $77 \%$ responden hanya tahu sekilas saja. ${ }^{(10)}$

Rendahnya pengetahuan informan tentang filariasis ini dapat dipengaruhi oleh terbatasnya informasi filariasis yang mereka terima. Informasi filariasis yang dapat diakses informan melalui penjelasan petugas kesehatan adalah penting. Sementara itu, sebagian besar penderita filariasis mendapat kunjungan rumah oleh petugas kesehatan hanya ada karena program pengobatan massal satu atau dua kali saja. Selain itu, sebagian besar penderita berpendidikan SD sehingga hal ini dapat mempengaruhi kesulitan informan dalam memahami informasi. Hal ini sesuai dengan teori yang menyatakan bahwa semakin banyak dan sering seseorang mendapatkan informasi maka pengetahuan orang tersebut akan semakin meningkat, begitupun sebaliknya. Semakin tinggi tingkat pendidikan seseorang maka akan memudahkan dirinya memahami informasi yang diterima. ${ }^{(11)}$ Pengetahuan tentang filariasis bagi penderita diperlukan untuk membentuk kecenderungan berperilaku positif dalam mencari pengobatan maupun 
perawatan mandiri yang baik. Tingkat pengetahuan mempengaruhi reaksi atau respon penderita filariasis sehingga ada kecenderungan melakukan suatu tindakan pengobatan segera yang mendukung. ${ }^{(10)}$

\section{Kepercayaan terhadap medis}

Kepercayaan terhadap medis merupakan keyakinan penderita filariasis untuk mencari pengobatan dan perawatan filariasis di fasilitas pengobatan medis. Sebagian besar percaya, pengobatan medis dapat menyembuhkan atau meringankan rasa sakitnya. Sedangkan lainnya tidak percaya namun pasrah karena tidak kunjung sembuh setelah berkali-kali berobat dan akhirnya merasa ragu jika ketidaknormalan kakinya bisa disembuhkan.

"Ya percaya. Ya perlu.. (setelah diperiksa ada bedanya?) Lebih baik" (KWL, 50 tahun)

Ketidakpercayaan terhadap medis tersebut sejalan dengan penelitian tentang asosiasi penyedia komunikasi dengan kepercayaan orang dewasa penderita penyakit sel sabit yang menyatakan bahwa ekspektasi atau perkiraan yang tidak terpenuhi dari seorang pasien dapat membuat kepercayaan terhadap layanan medis pasien tersebut rendah. ${ }^{(12)}$

\section{Beban psikososial}

Beban psikososial yang dirasakan informan diantaranya sempat merasa khawatir maupun minder dengan bengkak kaki atau tangan yang dialaminya. Penyakit filariasis tidak hanya bisa menimbulkan beban bagi penderita itu sendiri melainkan juga bagi anggota keluarganya. Hal ini diantaranya disampaikan oleh keluarga penderita karena beberapa tetangga yang mengutarakan ketakutan tertular bila dekat dengan penderita. Hal ini membuat penderita menjadi minder dan depresi serta takut keluar rumah untuk berobat. ${ }^{(13)}$

"Nggih raose nggih cok kulo niku cok grajasan kepikiran niku."

Ya rasanya ya kadang saya itu kadang waswas, kepikiran itu... (WLN, 50 tahun)

Penelitian lain yang sejalan tentang pengalaman hidup orang terinfeksi filariasis bahwa kecacatan yang bersifat irreversible atau tidak dapat kembali seperti semula menjadi pemicu utama terjadinya gangguan psikologis terhadap penderita, karena dapat menimbulkan rasa malu, cemas, hingga menarik diri dari lingkungannya. ${ }^{(7)}$ Analisis beban psikososial berdasarkan temuan di lapangan pada salah seorang informan yang bersikap tertutup dan menyembunyikan kakinya menggunakan kain sarung karena sudah mengalami pembengkakan kaki yang besar. Petugas puskesmas juga menuturkan bahwa selama ini informan memang bersifat tertutup dan cenderung menyembunyikan penyakitnya. Sebagian besar penderita merasa malu karena 
menderita filariasis yang menyebabkan bagian tubuhnya membengkak, sehingga mereka cenderung menyembunyikan diri atau menggunakan baju maupun celana yang longgar apabila hendak pergi. ${ }^{(10)}$

Beban berbeda disampaikan oleh keluarga informan, bahwa ada warga yang menyampaikan dirinya takut tertular filariasis sehingga ditakutkan menimbulkan diskriminasi pada penderita seperti dianggap membahayakan hingga timbul pengucilan. Diskriminasi merupakan ketidakadilan dan ketidakseimbangan perlakuan yang dilakukan untuk membuat perbedaan terhadap seseorang atau kelompok berdasarkan suatu hal. ${ }^{(14)}$ Sebuah penelitian tentang perspektif filariasis di daerah endemik Brazil menerangkan bahwa pasien merasa menjadi korban diskriminasi masyarakat akibat mengalami pembengkakan tubuh, termasuk dijauhi oleh suami mereka dan diminta untuk tidur di ruangan berbeda. Penderita pun mengalami permasalahan ekonomi akibat tidak diterima saat melamar pekerjaan. ${ }^{(15)}$

\section{Pendukung Pencarian Pengobatan dan Perawatan Mandiri}

\section{Keadaan ekonomi}

Keadaan ekonomi merupakan salah satu bagian dari karakteristik pendukung, yang dilihat melalui pekerjaan dan pendapatan informan. Sebagian besar informan bekerja pada sektor informal seperti petani, pedagang, dan tukang pijat keliling dengan penghasilan rendah dan tidak tetap, sedangkan sebagian penderita lainnya tidak bekerja. Sebagian besar ekonominya kurang dari upah minimum Kabupaten Wonosobo (< Rp 1.585.000,00 per bulan).

"Nganggur-nganggur tok, teng mriki mawon"

Hanya nganggur-nganggur, disini saja. (ZML, 30 tahun)

Meskipun kondisi terkini informan saat ini membutuhkan penanganan yang baik, namun kemampuan penderita dalam pencarian pengobatan dan melakukan perawatan mandiri ini tergantung kepada karakteristik pendukung, diantaranya adalah keadaan ekonomi. Sebagian besar informan dalam penelitian ini mempunyai keadaan ekonomi rendah dan cenderung tidak mengakses pengobatan medis secara berkala. Penderita filariasis lebih memilih memanfaatkan cara maupun bahan alami yang diyakini dapat meringankan penyakitnya, seperti memijat, merendaman kaki, maupun mengolesnya dengan minyak kelapa. Penelitian fenomenologi makna perawatan filariasis di Kecamatan Margaasih Kabupaten Bandung mengungkapkan ketidakmampuan keluarga dan kurangnya dukungan finansial dapat menyebabkan ketidakmampuan penderita untuk mencari pengobatan. Penderita yang 
tidak mampu secara finansial lebih sering memanfaatkan sumber-sumber dari alam dan memilih untuk tidak mendatangi petugas kesehatan. ${ }^{(16)}$ Ketidakmampuan secara finansial dapat menyebabkan penderita filariasis enggan melakukan pengobatan filariasis karena membutuhkan biaya mahal. ${ }^{(17)}$

\section{Keterpaparan dengan program filariasis}

Program Filariasis di beberapa puskesmas di Kabupaten Wonosobo berdasarkan wawancara dengan petugas kesehatan diantaranya adalah kegiatan kunjungan rumah untuk memantau kondisi terkini penderita, pemberian obat filariasis pertama kali setelah diketahui positif serta pemberian obat kembali saat pengobatan massal (POPM) pada tahun selanjutnya. Sebagian besar penderita mengaku pernah mendapat kunjungan rumah dari petugas kesehatan dan diberikan obat untuk diminum. Sedangkan dua penderita lainnya yang tidak diberikan obat dari petugas puskesmas disebabkan karena penderita saat itu tekanan darahnya sedang tinggi sehingga pemberian obat harus ditunda. Obat filariasis dapat meningkatkan tekanan darah seseorang, sehingga bila seorang penderita mempunyai tekanan darah diatas 120/80 mmHg maka tidak diindikasikan untuk diberikan obat filariasis. ${ }^{(1)}$
"Endak. Itu kemaren ga dikasih obat." (KWL, 50 tahun)

Hasil wawancara mendalam dengan petugas kesehatan didapatkan bahwa penderita yang belum diberi obat pada saat kunjungan rumah disebabkan karena pada saat dilakukan pemeriksaan awal, tekanan darahnya masih tinggi dan beberapa kali petugas mendatangi rumahnya kembali, penderita berpindah alamat dan sulit ditemui sehingga belum diberi obat sampai dengan saat penelitian ini berlangsung. Ketidaktahuan dan kebingungan penderita akan penyakitnya serta adanya stigma dari masyarakat membuat penderita mengisolasi diri dari lingkungannya. ${ }^{(10)}$

Karakteristik pendukung lainnya terkait perilaku pencarian pengobatan dan perawatan mandiri filariasis adalah keterpaparan penderita dengan program filariasis. Program fiariasis terutama kegiatan kunjungan rumah dapat dijadikan sebagai kegiatan peningkatan informasi sekaligus evaluasi praktik perawatan mandiri yang telah dilakukan oleh penderita. Sesuai dengan Permenkes nomor 94 tahun 2014, evaluasi ini disarankan untuk dilakukan secara bertahap, yaitu 2 minggu setelah mulai perawatan, 2 minggu setelah evaluasi pertama, evaluasi ketiga dan keempat setiap bulan, evaluasi kelima hingga ketujuh setiap 3 bulan, dan selanjutnya setiap 6 bulan. ${ }^{(1)}$ Akan tetapi, 
berdasarkan wawancara peneliti dengan sebagian besar petugas kesehatan menyatakan kegiatan kunjungan rumah belum dijadwalkan secara rutin dan masih sebatas pengawasan bidan desa untuk siaga jika terdapat keluhan pada kesehatan penderita. Apabila kegiatan kunjungan rumah untuk memberikan informasi filariasis dan evaluasi pelaksanaan perawatan mandiri pada penderita dapat terlaksana secara rutin, maka dapat membentuk kesadaran penderita filariasis dalam melakukan pengobatan dan perawatan mandiri yang baik dan teratur.

\section{Kebutuhan pencarian pengobatan dan perawatan mandiri}

Kebutuhan pengobatan dan perawatan mandiri dianalisis berdasarkan kondisi terkini informan. Seluruh informan mengalami pembengkakan kaki dengan kulit menebal dan kering. Seorang penderita mengalami komplikasi penyakitnya berupa kehilangan penglihatan dan mengalami gangguan susah buang air kecil. Sedangkan yang lainnya mengalami luka dan bernanah di sela jari kaki yang sulit sembuh. Komplikasi penyakit filariasis dapat terjadi bila tidak melakukan pengobatan segera hingga menimbulkan disabilitas. $^{(18)}$

Terdapat pengaruh interaksi sosial terhadap diri individu yang sedang berkembang menjadi matang secara fisik dan psikologis. Perkembangan psikososial yang dialami pada usia lanjut yaitu tahap integritas diri versus putus asa (ego integrity versus despair). ${ }^{(19)}$ Penderita filariasis memiliki kebutuhan fisiologis diantaranya terbebas dari rasa sakit, kebutuhan keselamatan dan keamanan diantaranya terbebas dari ancaman kecacatan filariasis. Oleh sebab itu, dukungan positif dari orang sekitar sangat diperlukan dalam upaya pemberian motivasi penderita untuk segera sembuh dengan rajin meminum obat yangtelah disediakan. ${ }^{(20)}$ Sangat penting untuk keluarga, masyarakat dan petugas kesehatan bersama-sama menghindari diskriminasi serta memberi dukungan psikososial agar penderita mampu melakukan pengobatan dan perawatan mandiri teratur.

\section{Persepsi beratnya filariasis}

Seluruh informan merasakan beratnya penyakitnya pada saat muncul gejala yang dirasakan sangat sakit dan mengganggu. Selain itu, pembengkakan kakinya juga mengakibatkan berat untuk berjalan. Sebagian besar informan mengalami keluhan dan gejala penyakitnya pada malam hari menjelang pagi seperti kaki pegal hingga punggung, kemudian gatal dan demam.

“Abot. Lha niku nek mlaku angel." 
Berat. Ya ini kalo buat berjalan susah. (FTN, 22 tahun)

Seluruh informan dalam penelitian ini memiliki persepsi bahwa filariasis merupakan penyakit yang berat karena rasanya sangat sakit ketika kambuh. Penderita filariasis mengalami gejala nyeri yang dapat mengakibatkan keterbatasan fisik karena ektrimitasnya membesar, sehingga menimbulkan perasaan berat dan sulit untuk menggerakkan tubuhnya yang membengkak. ${ }^{(7)}$

\section{Persepsi ancaman filariasis}

Sebagian besar informan menganggap penyakit ini berbahaya atau mengancam karena khawatir pembengkakan kakinya tidak bisa disembuhkan, serta pada saat kambuh terasa sangat sakit sehingga tidak bisa beraktivitas maupun bekerja. Akan tetapi, terdapat informan menganggap tidak berbahaya karena dirasakan tidak mengganggu organ tubuh lainnya.

"Nggih bahaya tak kira nggih. Wong nyatane tetep jan lara temenan niku mbak. Umate sing mesti amben bulan jarak 3 dina. Teruse ngoten rasa lemes, tapi ya tetep bisa tak gawa ngarit, bisa ngapa ngeten. Sing jenenge berat ngoten sekitar 3 jam-an lah sing rasane ora genah"

Ya saya kira bahaya. Karena kenyataannya tetap sakit beneran mbak. Kambuhnya pasti setiap bulan dengan jarak 3 hari. Selanjutnya merasa lemas, tapi ya tetap bisa saya bawa untuk merumput, bisa mengerjakan apa begitu. Yang rasanya berat itu sekitar 3 jam lah yang rasanya tidak karuan. (NSQ, 42 tahun)

Persepsi ancaman filariasis menunjukkan sebagian besar informan menganggap penyakit ini berbahaya bagi dirinya. Hal ini dikarenakan adanya rasa khawatir jika pembengkakan kakinya tidak bisa disembuhkan. Selain itu, informan juga mempunyai persepsi ancaman filariasis yaitu rasa sakit di kaki dan punggungnya pada saat kambuh dapat mengganggu aktivitas dan tidak dapat bekerja. Dalam penelitian tentang pengalaman hidup penderita filariasis, disebutkan bahwa penderita yang mengalami kecacatan fisik dapat menghambat aktivitas hingga berdampak keadaan ekonominya karena tidak dapat bekerja untuk memperoleh penghasilan. $^{(7)}$

\section{Persepsi terhadap manfaat dan hambatan melakukan pengobatan}

Sebagian besar informan menyatakan manfaat berobat adalah untuk menghilangkan rasa sakit dan membuat kondisi pembengkakannya lebih baik, sedangkan informan lainnya menyatakan tidak terlalu merasakan manfaat berobat karena kondisi kakinya tetap bengkak. Sedangkan hambatan terbesar yang dirasakan diantaranya adalah kesulitan ekonomi dan rasa takut jika pengobatannya tidak membawa hasil pada kesembuhannya. 
"Ya kalo pribadi, keluarga, ya pinginnya ya sembuh. Tapi carane pengobatan gitu udah bingung."

Ya kalau saya pribadi, keluarga, ya inginnya sembuh. Tapi caranya pengobatan gitu sudah bingung. (ID, keluarga informan)

Dua informan menyatakan bahwa pengobatan yang dijalani tidak menghasilkan kesembuhan seperti yang mereka harapkan. Adapun persepsi hambatan pengobatannya adalah kesulitan ekonomi dan rasa takut jika melakukan pengobatan lagi hasilnya tetap tidak menyembuhkan penyakitnya. Faktor ekonomi menjadi salah satu penentu penderita untuk melakukan pengobatan atau membiarkan penyakitnya karena pengobatan filariasis membutuhkan biaya besar. ${ }^{(16)}$ Selain itu, hambatan pencarian pengobatan berupa perasaan bingung dan perasaan tidak menentu dapat muncul sebagai akibat dari ketidakpastian masa depan termasuk ketidakpastian proses penyembuhan penyakit filariasis yang dialami. $^{(7)}$

Pengobatan filariasis terutama bagi penderita yang telah mengalami pembengkakan memang membutuhkan waktu lama dan tidak sembuh dengan cepat sesuai ekspektasi penderita pada umumnya. Tata laksana pengobatan filariasis dalam Permenkes RI nomor 94 tahun 2014 menggunakan Diethylcarbamazine Citrate (DEC) dan albendazole. Kinerja dari obat ini bagi keberadaan mikrofilaria adalah menurunkan jumlahnya selama satu tahun, sehingga perlu pengulangan konsumsi obat sekali dalam setahun selama lima tahun untuk mempertahankan mikrofilaria dalam darah penderita tetap rendah. Sedangkan kinerja dari obat filariasis bagi makrofilaria adalah membunuh maupun menghambat perkembangbiakan cacing dewasa tersebut. Efek samping pengobatan ini dapat menimbulkan reaksi alergi, yang justru menandakan obat tersebut berhasil berekasi dengan cacing filaria. Adapun praktik bedah kosmetik dilakukan apabila terdapat indikasi medis, sehingga penderita pada umumnya dianjurkan melakukan perawatan mandiri untuk mencegah indikasi medis yang merujuk pada tindakan bedah tersebut. ${ }^{(1)}$ Oleh karena sifat pengobatan filariasis yang harus dilakukan bertahap dan rutin, penting bagi penderita untuk memahami dan menyadari bahwa pengobatan filariasis tidak dapat instan mencapai kesembuhan. Pengobatan filariasis yang tidak berlanjut dapat menyebabkan penderita tersebut tetap menjadi sumber penularan dan memungkinkan terjadinya kecacatan menetap.

\section{Perilaku pencarian pengobatan}

Diagram pathway pada gambar 1 menunjukkan bahwa sebagian besar informan hanya melakukan pengobatan 
medis. Sedangkan informan lain mengaku pernah juga mencoba berobat nonmedis. Perilaku pencarian pengobatan informan sebelum ditemukan petugas kesehatan menunjukkan terdapat dua informan yang sempat mencoba pengobatan nonmedis.

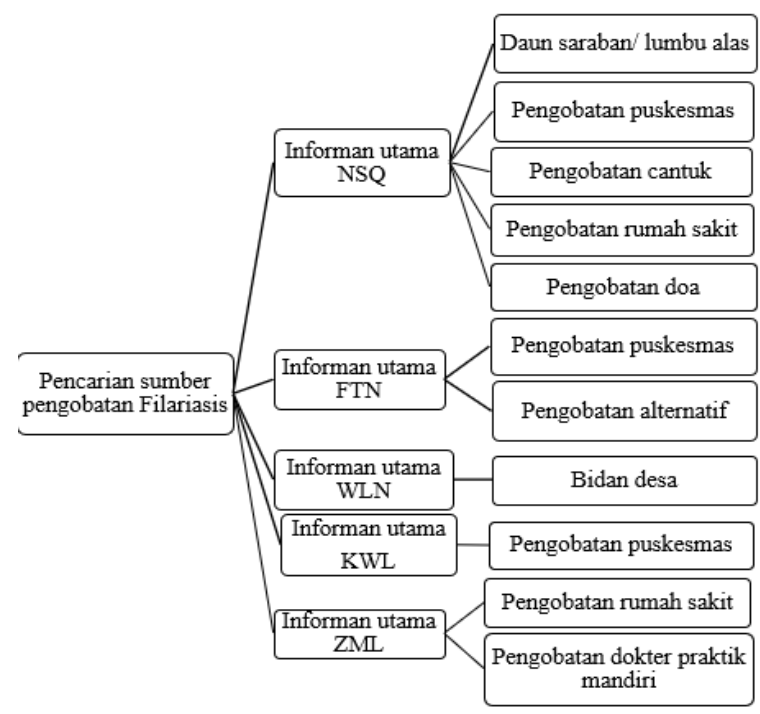

Gambar 1. Diagram pathway pencarian sumber pengobatan filariasis

Pengalaman pencarian pengobatan nonmedis tersebut di antaranya dengan menggunakan daun lumbu alas, pengobatan alternatif cantuk (blood cupping) di Magelang, serta pengobatan doa ke orang pintar/ kiai.

Kecenderungan perilaku informan dalam mencari pengobatan nonmedis disebabkan karena penyakitnya tidak kunjung sembuh seperti yang diharapkan setelah berobat secara medis. Informan penderita filariasis kronis mengungkapkan penderita merasa bosan dan berusaha mencari pengobatan lain karena proses pengobatan medis terlalu lama dan tidak memberikan hasil yang diharapkan. ${ }^{(10)}$ Banyak penderita filariasis menggunakan tumbuh-tumbuhan sebagai kompres atau dimakan, juga mencari pengobatan dengan mendatangi dukun karena menganggap filariasis disebabkan oleh nasib buruk atau gangguan roh halus. ${ }^{(16)}$

\section{Praktik perawatan mandiri}

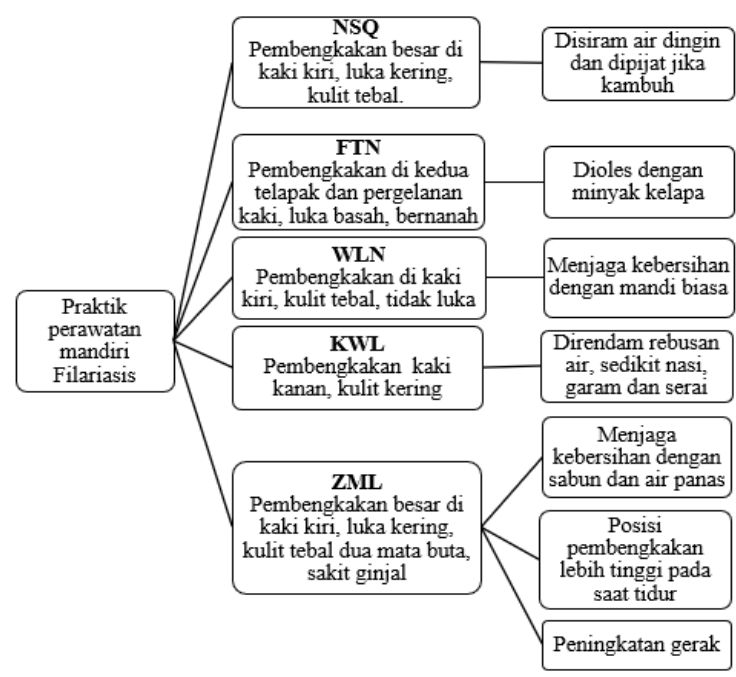

Gambar 2. Diagram pathway praktik perawatan mandiri penderita filariasis

Diagram pathway pada gambar 2 di atas menunjukkan perawatan mandiri yang dilakukan informan berupa penggunaan teknik pijat dan menggunakan ramuan tradisional serta meningkatkan gerak anggota tubuh terutama daerah pembengkakan.

Praktik perawatan mandiri yang direkomendasikan oleh petugas kesehatan harus disesuaikan dengan kondisi, gejala maupun keluhan dari penderita. Rekomendasi perawatan mandiri 
ditekankan pada praktik menjaga kebersihan daerah pembengkakan serta pengobatan simtomatis. Namun masih banyak penderita yang belum melakukan perawatan dengan baik. Temuan dalam penelitian ini menunjukkan adanya ketidakpatuhan sebagian besar penderita dalam melakukan perawatan mandiri yang direkomendasikan oleh petugas kesehatan.

Sejalan dengan penelitian terdahulu tentang perilaku pencarian pengobatan dan praktik perawatan mandiri pada penderita filariasis limfedema yang menunjukkan hanya beberapa penderita yang melakukan perawatan mandiri sesuai rekomendasi medis seperti menjaga kebersihan dan meningkatkan gerak anggota tubuh yang mengalami pembengkakan. ${ }^{(21)}$

\section{SIMPULAN}

Perilaku pencarian sumber pengobatan menunjukkan dua informan pernah berobat nonmedis. Seluruh informan terlambat dalam mengakses pengobatan medis filariasis karena sudah mengalami pembengkakan kaki. Praktik perawatan mandiri sebagian besar penderita belum sesuai dengan perawatan mandiri yang direkomendasikan petugas kesehatan.

Institusi kesehatan perlu menambah informasi tentang filariasis kepada penderita, keluarga dan masyarakat secara intensif bukan hanya saat kegiatan POPM filariasis saja tetapi juga melakukan pengendalian vektor filaria melalui pemberantasan sarang nyamuk serta peningkatan penemuan dini filariasis melalui screening darah jari. Perawatan mandiri pada penderita filariasis klinis juga perlu dilakukan evaluasi untuk mengetahui perawatan yang telah dilaksanakan penderita. Tenaga kesehatan masyarakat sebaiknya melaksanakan intervensi terkait perilaku pengobatan dan perawatan mandiri filariasis yang baik. Masyarakat harus patuh meminum obat pencegahan filariasis yang diberikan melalui POPM, serta melakukan kegiatan pemberantasan sarang nyamuk secara rutin. Selain itu penting untuk meningkatkan peran masyarakat dan keluarga dalam mendorong penderita meminum obat filariasis dan melakukan perawatan mandiri secara teratur.

\section{KEPUSTAKAAN}

1. Kementerian Kesehatan RI. Peraturan Menteri Kesehatan Republik Indonesia Nomor 94 Tahun 2014 tentang Penanggulangan Filariasis. Jakarta: Kemenkes RI; 2014.

2. Kementerian Kesehatan RI. Rencana Nasional Program Akselerasi Eliminasi Filariasis di Indonesia. Jakarta: Kemenkes RI; 2010.

3. Muslim H. Parasitologi untuk Keperawatan. Jakarta: Buku Kedokteran EGC; 2009. 
4. WHO. Lymphatic Filariasis Situation and Trends [Internet]. 2016. Tersedia di:

http://www.who.int/gho/neglected_di seases/lymphatic_filariasis/en/

5. Kementerian Kesehatan RI. Infodatin: Situasi Filariasis di Indonesia Tahun 2015. Jakarta: Kemenkes RI; 2016.

6. Dinas Kesehatan Kabupaten Wonosobo. Profil Kesehatan Kabupaten Wonosobo Tahun 2017. Wonosobo: Dinas Kesehatan Wonosobo; 2017.

7. Lismayanti L, Ibrahim K, Meilianingsih L. Pengalaman Hidup Orang Terinfeksi Filariasis. Jurnal Keperawatan Padjadjaran. 2013;1(1):18-29.

8. Maryanti E, Adriyani S. Gambaran Penderita Filariasis di Kabupaten Meranti Provinsi Riau. Jurnal Ilmu Kesehatan. 2016;10(2):67-70.

9. Kementerian Kesehatan RI. Rencana Strategis Kementerian Kesehatan Tahun 2015-2019. Jakarta: Kemenkes RI; 2015.

10. Sulianti. Tinjauan Psikologi Kesehatan pada Penderita Penyakit Kaki Gajah Kronis di Kabupaten Bandung. Jurnal Ilmu Psikologi. 2014;1(2):186-203.

11. Budiman, Riyanto. Kapita Selekta Kuesioner Pengetahuan dan Sikap dalam Penelitian Kesehatan. Jakarta: Salemba Medika; 2013.

12. Haywood C, Lanzkron S, Ratanawongsa N, Bediako S, Lattimer L, Powe N, et al. The Association of Provider Communication with Trust among Adults with Sickle Cell Disease. Journal of General Internal Medicine. 2010;25(6):543-8.

13. Abdulmalik J, Nwefoh E, Obindo J, Dakwak S, Ayobola M, Umaru J, et al. Emotional Difficulties and Experiences of Stigma Among Persons with Lymphatic Filariasis in Plateau State, Nigeri. Health Human Rights. 2018;20(1):27-40.

14. Fulthoni. Memahami Diskriminasi. Jakarta: ILRC; 2009.

15. Dreyer G, Mattos D. Perspective of Elephantiasis in an Endemic Area of Brazil. Journal of Lymphoedema. 2007;2(1):24-31.

16. Nadirawati. Studi Fenomenologi Makna Perawatan Filariasis untuk Klien Dewasa di Kecamatan Margaasih Kabupaten Bandung, 2010 [Internet]. Bandung: Stikes Jenderal A Yani; 2010. p. 1-11. Tersedia di:http://www.stikesaya ni.ac.id/publikasi/e-journal/filesx/201 0/201008/201008-006.pdf

17. Febrianto B, Maharani A, Widiarti. Faktor Risiko Filariasis di Desa 
Samborejo, Kecamatan Tirto,

Kabupaten Pekalongan Jawa Tengah.

Bul Penelit Kesehat. 2008;36(2):4858.

18. Kemenkes RI. Infodatin: Menuju Indonesia Bebas Filariasis. Jakarta; 2018.

19. Devamethia. Pengalaman Lansia Terlantar dalam Menghadapi Krisis. Tahap Kedelapan (Ego Integrity vs Despair) [Skripsi]. Yogyakarta: Fakultas Psikologi Universitas Sanata Dharma Yogyakarta; 2019.

20. Nadirawati. Hubungan Dukungan Kepala Keluarga dengan Partisipasi
Keluarga dalam Program Eliminasi (Minum Obat) Filariasis di Majasetra Kabupaten Bandung. Jurnal Keperawatan Soedirman. 2012;6(1):47-55.

21. Adhikari R, Sherchand J, Mishra S, Ranabhat K, Pokharel A, Devkota P, et al. Health-Seeking Behaviors and Self-Care Practices of People with Filarial Lymphoedema in Nepal: A Qualitative Study. Journal of Tropical Medicine. 2015;2015:1-6. 